Original Research Article

\title{
Analysis of adverse drug reactions encountered in a tertiary care hospital: a cross sectional study
}

\author{
Syed Hussain F.*, Sathyanarayanan V., Jamuna Rani R.
}

Department of Pharmacology, SRM Medical College Hospital and Research Centre, SRM

Institute of Science and

Technology, Kattankulathur, Tamil Nadu, India

Received: 26 March 2018

Accepted: 25 April 2018

\section{*Correspondence to:}

Dr. Syed Hussain F.,

Email: dr.syedhussain91@ gmail.com

Copyright: (C) the author(s), publisher and licensee Medip Academy. This is an openaccess article distributed under the terms of the Creative Commons Attribution NonCommercial License, which permits unrestricted noncommercial use, distribution, and reproduction in any medium, provided the original work is properly cited.

\begin{abstract}
Background: Adverse drug reactions are due to hazards of drug therapy and can occur with any class of drugs. The aim of this study was to evaluate and record adverse drug reactions reported from various departments of a tertiary care hospital.

Methods: A Cross Sectional study conducted in a tertiary care hospital for a period of 4 months from March to June 2017 after Institutional Ethics Committee approval. ADRs reports collected and analyzed for causality, severity and preventability by international standardized scales.

Results: A total of 38 ADR's were reported during the study period with male predominance (58\%). Most of the ADR's (42\%) were common in patients in the age group 19-39 years. More number of ADR's were from Medicine (29\%). Most commonly affected organ systems were skin $(45 \%)$. The drugs mostly accounted were antibiotics (55\%) especially Cephalosporins (33\%). According to Naranjo's causality assessment scale $74 \%$ of reactions were probable, $26 \%$ were possible, Modified Hartwig and Seigel severity assessment scale revealed 45\% ADRs to be moderate, $42 \%$ were mild and $13 \%$ were severe, Modified Schumock and Thorton Preventability assessment scale which revealed $61 \%$ ADRs were not preventable, $32 \%$ were probably preventable, $7 \%$ were definitively preventable. Conclusions: Adverse Drug Reactions are common and some of them resulted in increased healthcare cost due to need of some interventions and increased length of hospital stay. The health system should promote the spontaneous reporting of ADR's. The proper documentation and periodic reporting to Pharmacovigilance Centres is required to ensure drug safety.
\end{abstract}

Keywords: Adverse Drug Reactions, Causality, Pharmacovigilance, Spectrum, Spontaneous reporting

\section{INTRODUCTION}

The World Health Organization (WHO) defines ADR as "a response to a drug that is noxious and unintended and occurs at doses normally used in man for the prophylaxis diagnosis or therapy of disease, or for modification of physiological function". ${ }^{1}$ Adverse drug reaction is the major limitation in providing health care to patients at a global level. The overall rate of ADR - 6.7\%. ADR account for $5 \%$ of all hospital admissions. Also occurs in 10-20\% of hospitalized patients. They are the fourth leading causes of death. All drugs are having the potential to cause ADR. ${ }^{2}$
ADRs related hospitalizations have consistently increased which has caused an economic burden to the developing countries like India. ${ }^{3}$ ADRs are commonly encountered at hospital set up where poly pharmacy is practiced usually. ${ }^{4}$ India is the fourth largest pharmaceutical producer in the world and is recognized as an important clinical trial hub in the world. Due to introduction of many drugs in the country, it has become essential to have an effective Pharmacovigilance system nationwide in order to protect interest of public health. The main function of this programme involves data collection and analysis of ADRs. ${ }^{5}$ 
The Central Drugs Standard Control Organization (CDSCO), New Delhi, under the guidance of Ministry of Health and Family Welfare, Government of India has initiated a countrywide pharmacovigilance programme (PvPI) in 2010, with the All India Institute of Medical Sciences (AIIMS), New Delhi as the National Coordinating Centre for monitoring ADRs in the nation. Our hospital is one of the centres for monitoring and reporting ADRs through this programme.

\section{METHODS}

\section{Study design}

After obtaining approval of the Institutional Ethics Committee, a cross sectional study and spontaneous reporting study involving active methods (pharmacist actively seeking suspected ADRs) and passive methods (stimulating clinicians to report suspected ADRs) was carried out in all departments of SRM MCH and RC tertiary care teaching hospital, in Potheri for a period of four months.6,7 38 Patients of all age groups who developed Adverse Drug Reactions were included for the study.

Oral Informed consent was obtained from the patients. The data for the study were taken from case sheets, investigation reports, personal interviews with clinicians, and personal interviews with patient or patient's attendant, past history of medications and reports of Medical and surgical interventions.

\section{Assessment scales}

The reported ADRs were assessed for causality using Naranjo's probability scale. The total score was calculated, based on the score, it was categorized as certain (score >9), probable (score 5-8) and possible (score 1-4). ${ }^{8}$ The severity of ADRs were assessed by using Modified Hartwig's criteria into seven levels. Level 1 and 2 classified as mild category, level 3 and 4 considered as moderate and level 5, 6 and 7 grouped as severe category. ${ }^{9}$ The Preventability of the reported ADRs were assessed using the Modified Schumock and Thorton scale. ${ }^{10}$

\section{Data collection}

ADR's were collected by spontaneous reporting system from outpatient departments as well as wards. The contact number and email id of the study author were provided to the physicians. The collected information included. Patient's age, gender. Reporting department. Description of reaction. Name of the suspected drug. Route of administration of drug and Dosage and filled in ADR form.

\section{Statistical analysis}

SPSS software version 17 and Excel Sheet were used for data analysis.

\section{RESULTS}

Total of 38 patients were reported to experience ADR during 4 months study period. Out of 38 patients, $22(58 \%)$ patients were males while $16(42 \%)$ patients were females. Number of ADR's reported in each month. March - 9 (25\%) April - 8 (23\%) May - 10 (27\%) June - 9 (25\%). Most of the reactions were type A $(68 \%)$ rather than type B $(32 \%)$ and thus predictable. ADR's based on route of administration: Parenteral - 28 (74\%) Enteral - 10 (26).

A total of 38 ADR's was reported during the study period with male predominance (Table 1). Most of the ADR's (42\%) were common in patients in the adult age group (Table 1).

Table 1: Gender and age wise distribution of ADRs.

\begin{tabular}{|llll|}
\hline Age range & Male & Female & Total patients (\%) \\
\hline $1-18$ & 2 & 2 & $4(11 \%)$ \\
\hline $19-39$ & 7 & 9 & $16(42 \%)$ \\
\hline $40-59$ & 7 & 5 & $12(32 \%)$ \\
\hline$\geq 60$ & 6 & 0 & $6(16 \%)$ \\
\hline Total patients & 22 & 16 & 38 \\
\hline
\end{tabular}

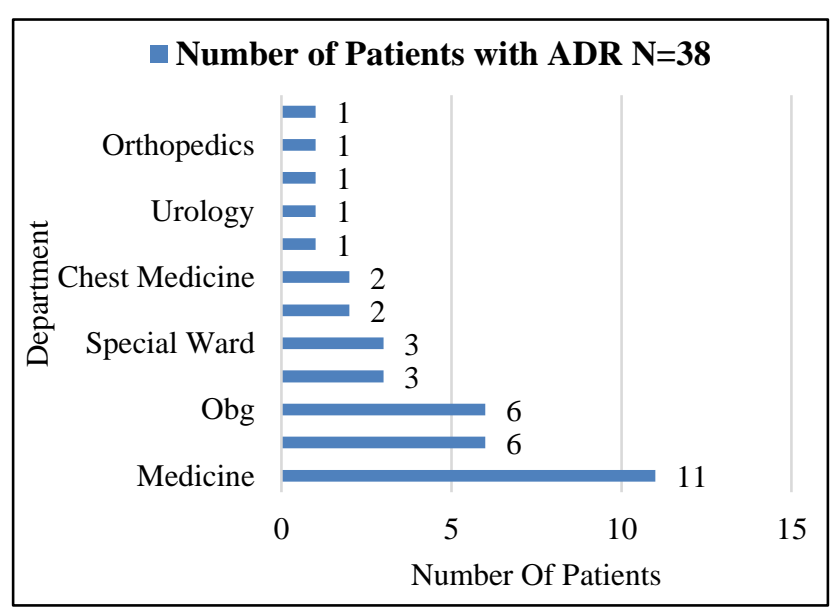

Figure 1: Department wise distribution of ADRs.

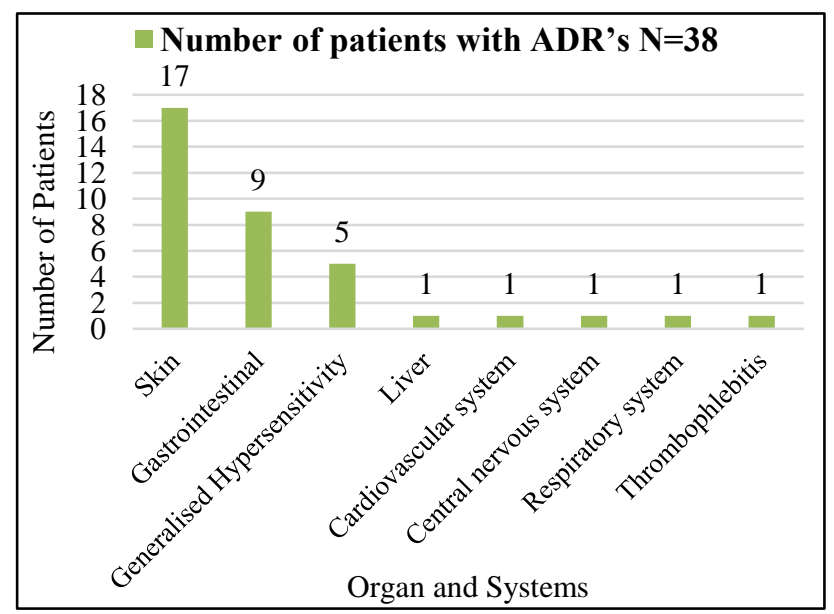

Figure 2: Organ and systems affected by ADRs. 
In terms of departments, more number of ADR's were from Medicine (29\%) followed by Surgery (16\%) and OG (16\%) (Figure 1). Most commonly affected organ systems were skin $(45 \%)$ followed by GIT $(24 \%)$ (Figure 2$)$.

Table 2: Drugs implicated in ADRs.

\begin{tabular}{|c|c|c|c|}
\hline Drug group & \multicolumn{2}{|c|}{ Name of the drug } & $\begin{array}{l}\text { No. of } \\
\text { ADR's }\end{array}$ \\
\hline \multirow[t]{10}{*}{$\begin{array}{l}\text { Antibiotics } \\
21(55 \%)\end{array}$} & $\begin{array}{l}\text { Cephalospo } \\
\text { rins -7 } \\
(33 \%)\end{array}$ & Cefotaxime & 4 \\
\hline & & Ceftrioxone & 2 \\
\hline & & Cefperazone & 1 \\
\hline & Quinolones & Ofloxacin & 2 \\
\hline & & Ciprofloxacin & 1 \\
\hline & $\begin{array}{l}\text { Pencillins - } \\
6(29 \%)\end{array}$ & Pencillin & 2 \\
\hline & & Amoxycllin & 2 \\
\hline & & Augmentin & 1 \\
\hline & & Piperacilln & 1 \\
\hline & Others & $\begin{array}{l}\text { Azithromycin, } \\
\text { Amikacin, } \\
\text { Septran, } \\
\text { Linezolid, } \\
\text { Metronidazole }\end{array}$ & 5 \\
\hline \multirow[t]{2}{*}{ Analgesics } & \multicolumn{2}{|l|}{ Diclofenac } & 4 \\
\hline & \multicolumn{2}{|c|}{ Paracetamol } & 2 \\
\hline $\begin{array}{l}\text { Anti-cancer } \\
\text { drugs }\end{array}$ & \multicolumn{2}{|c|}{$\begin{array}{l}\text { Oxaliplatin, Carboplatin, } \\
\text { Adriamycin }\end{array}$} & 3 \\
\hline Enzymes & \multicolumn{2}{|c|}{$\begin{array}{l}\text { Hepamerz, Pancrealipase, } \\
\text { Cerebroprotein hydroxylate }\end{array}$} & 3 \\
\hline Haematinics & \multicolumn{2}{|c|}{ Hemfer } & 1 \\
\hline OHA & \multicolumn{2}{|c|}{ Metformin } & 1 \\
\hline TCA & \multicolumn{2}{|c|}{ Amitriptylline } & 1 \\
\hline $\begin{array}{l}\text { Local } \\
\text { anesthetic }\end{array}$ & \multicolumn{2}{|c|}{ Lignocaine } & 1 \\
\hline Antiemetic & \multicolumn{2}{|c|}{ Perinorm } & 1 \\
\hline Others & \multicolumn{2}{|c|}{ RL, Radiocontrast media } & 2 \\
\hline
\end{tabular}

Table 3: Causality assessment of ADRs.

\begin{tabular}{|ll|}
\hline \multicolumn{2}{|l|}{ Causlity assessment (Naranjo's scale) } \\
\hline Parameters & Number of ADR's (\%) N=38 \\
\hline Definite $(\geq 9)$ & $4(11 \%)$ \\
\hline Probable $(5-8)$ & $24(63 \%)$ \\
\hline Possible $(1-4)$ & $10(26 \%)$ \\
\hline Doubtful $(\leq 0)$ & 0 \\
\hline
\end{tabular}

The drugs mostly accounted were antibiotics (55\%) especially Cephalosporins (33\%) (Table 2). According to Naranjo's causality assessment, 74\% of reactions were probable, $26 \%$ were possible (Table 3). Severity assessment by Modified Hartwig and Seigel scale revealed $45 \%$ ADRs to be moderate, $42 \%$ were mild and $13 \%$ were severe (Table 4). Preventability assessment by modified Schumock and Thorton scale which revealed $61 \%$ ADRs were not preventable, $32 \%$ were probably preventable, $7 \%$ were definitively preventable (Table 5).
Table 4: Severity assessment of ADRs.

\begin{tabular}{|c|c|}
\hline \multicolumn{2}{|c|}{$\begin{array}{l}\text { Severity assessment (Modified Hartwig and } \\
\text { SEIGEL Scale) }\end{array}$} \\
\hline Parameters & Number of ADR's (\%) $\mathrm{N}=38$ \\
\hline Mild & $16(42 \%)$ \\
\hline Moderate & $17(45 \%)$ \\
\hline Severe & $5(3 \%)$ \\
\hline
\end{tabular}

Table 5: Preventability assessment of ADRs.

\begin{tabular}{|ll|}
\hline \multicolumn{2}{|l|}{ Modified Schumock and Thorton Scale } \\
\hline Parameters & Number of ADR's (\%) N=38 \\
\hline Not preventable & $23(61 \%)$ \\
\hline Probably preventable & $12(32 \%)$ \\
\hline Definitely preventable & $3(7 \%)$ \\
\hline
\end{tabular}

\section{DISCUSSION}

In this study 38 ADR's were reported, of which majority $(86 \%)$ of the drugs were withdrawn for the management of ADR and re-challenge was not done. Majority of ADRs (42\%) were seen in adult age group (Table 1) which was comparable with the previous study by Sharma et al where it was $50.4 \% .{ }^{11}$ It is likely that this population is attending hospital more frequently and is a major population receiving drug therapy. The number of ADRs were high in General Medicine and General Surgery departments due to amplified use of antibiotics in these departments for the treatment and prophylaxis of various diseases and also since the patients admitted were with multiple comorbidities requiring poly pharmacy (Bar 1) these results in concurrence with the observation done by Vora et al. ${ }^{12}$

The most frequent ADRs were due to the antibiotics which could be associated with increased frequency of prescription of antibiotics. Among the ADRs, major proportions of adverse reactions were seen with Betalactam antibiotics (Table 2) which were similar to the observation by Rodriguez-pena et al, as well as by Raut et al. ${ }^{13,14}$ Since Beta-lactam antibiotics is the one of the most common antibiotics used by the practicing doctors. ${ }^{15}$ In accordance with previous studies by Misbah $\mathrm{M}$ et al, Oshikoya et al, Shareef et al and Suthar et al, the present study showed the predominance of cutaneous manifestations (Column 1). ${ }^{16-19}$ On analyzing the fate of the suspected drugs, it was found that the drug was withdrawn in most of the cases and the dose was reduced in some while no change was made in others considering the risk benefit ratio in particular patients. Most of the ADR's were type A - predictable. Extension of pharmacological effect were commonly found.

According to Naranjo's scale most of the ADR's were probable, since re-challenge was not done in many patients due to ethical issues we didn't get definite relationship. The causality assessment of the reported ADRs according to the Naranjo's scale revealed that no reactions were 
certain and most of them were probable with a lesser number of possible ADRs. This data is in correlation with the study of Jose et al. ${ }^{20}$

As per Hartwig criteria, most of the ADR reports were moderate in nature - patients required discontinuation of offending drug and treatment for ADR's. Majority of the patients recovered completely from the ADR since most of the reactions were moderate $(45 \%)$ this result was in accordance with Shamna et al and Kala et al were majority was moderate reactions followed by mild and severe ones. $^{6,7}$

According to Modified Schumock and Thorton scale, most of the ADR's were non-preventable. Those definitely preventable cases have a previous history of similar reaction following same drug intake; which shows the lack of awareness. In probably preventable cases, proper precautionary steps were not taken in few cases. On evaluation of preventability of the ADRs it was evident that most of them were not preventable $61 \%(n=38)$ which was similar to the results of Jose et al and Adithan S, et al (Table 5). ${ }^{21,22}$ However, the more common reactions like nausea and vomiting belonged to the category of "definitely preventable".

The significance of this study is to emphasize the awareness to the health-care providers on vigilant monitoring of ADRs and promptly reporting the same so as to prevent the occurrence of the reactions in the vulnerable population. Although the present study has some limitations as it is an analytical study for a very short duration and involved small study population still this study would definitely give an insight into the pattern of ADRs in tertiary health care centres and may help to increase awareness for further Pharmacovigilance studies.

\section{CONCLUSION}

Adverse Drug Reactions are common and some of them resulted in increased healthcare cost due to need of some interventions and increased length of hospital stay. The health system should promote the spontaneous reporting of ADRs. The proper documentation and periodic reporting to Pharmacovigilance Centres is required to ensure drug safety.

\section{ACKNOWLEDGEMENTS}

Authors are grateful to their respectable Medical Director, Dean (Medical), Medical Superintendent for their support and granting permission to carry out this study. They also thank their teachers and their colleagues for helping them in this study.

Funding: No funding sources Conflict of interest: None declared

Ethical approval: The study was approved by the Institutional Ethics Committee

\section{REFERENCES}

1. Gershanik J, Boecler B, Ensley H, McCloskey S, George W. The gasping syndrome and benzyl alcohol poisoning. Engl J Med. 1982;307(22):1384-8.

2. Tripathi KD. Essentials of Medical Pharmacology, JP Brothers, $7^{\text {th }}$ Ed, New Delhi; 2013:82-91.

3. Zhang M, Holman CDJ, Preen DB, Brameld K. Repeat adverse drug reactions causing hospitalization in older Australians: a population-based longitudinal study 1980-2003. Br J Clin Pharmacol. 2007;63:163-70.

4. Kaur S, Kapoor V, Mahajan R, Lal M, Gupta S. Monitoring of incidence, severity, and causality of adverse drug reactions in hospitalized patients with cardiovascular disease. Indian $\mathrm{J}$ Pharmacol. 2011;43(1):22-6.

5. Patil JS. Pharmacovigilance in India. J Pharmacovigilanace. 2014;2:2.

6. Kala. P, Jamuna Rani. R, Sangeetha Raja. A Cross Sectional Study of Adverse Drug Reactions in A Tertiary Care Teaching Hospital. International Journal of Pharma and Bio Sciences. 2015 Jun;6(2). [Cited 2018 Mar 24].

7. Shamna M, Dilip C, Ajmal M, Linu Mohan P, Shinu C, Jafer CP. A prospective study on Adverse Drug Reactions of antibiotics in a tertiary care hospital. Saudi Pharmaceutical Journal: SPJ. 2014;22(4):3038.

8. Naranjo CA, Busto U, Sellers EM, Sandor P, Ruiz I, Roberts EA. Method for estimating the probability of adverse drug reactions. Clin Pharmacol Ther. 1981;80:289-95.

9. Hartwig SC, Siegel J, Schneider PJ. Preventability and severity assessment in reporting adverse drug reactions. Am J Hosp Pharm. 1992;49:2229-32.

10. Schumock GT, Thornton JP. Focusing on the preventability of adverse drug reactions. Hosp Pharm. 1992;27:538. [PubMed: 10118597]

11. Sharma VK, Sethuraman G, Kumar B. Cutaneous adverse drug reactions: Clinical pattern and causative agents - a 6 year series from Chandigarh, India. J Postgrad Med. 2001;47(2):95-9.

12. Vora MB, Trivedi HR, Shah BK, Tripathi CB. Adverse drug reactions in inpatients of internal medicine wards at atertiary care hospital: A Prospective cohort study, J Pharmacol Pharmacother. 2011;2(1):21.

13. Rodriguez-Pena R, Pankaj M, Srivastava P, Martin E, Blanca-Lopez N, Mayorga C, Torres MJ. Allergic reactions to beta-lactams. Expert opin Drug Saf. 2006;5(1):31-48.

14. Raut A, Pawar A, Pankaj M, Srivastava P, Mishra A. Clinical pattern and severity of cutaneous adverse reactions. Int J Pharm Pharm Sci. 2013;5(2):612-6.

15. Bhattacharya $S$. The facts about penicillin allergy: A review. J Adv Pharm Technol Res. 2010;1(1):11-7.

16. Misbah HM, Girhepunje K, Pal R, Sugra SS. Incidence of adverse drug reactions in a tertiary care hospital: a systematic review and metaanalysis of prospective studies. Der Pharmacia Lettre. 2010;2(3):358-68. 
17. Oshikoya KA, Njokanma OF, Chukwara HA, Ojo IO. Adverse drug reactions in Nigerian children. Paediatr. Perinat. Drug Ther. 2007;8:81-8.

18. Shareef SM, Naidu CDM, Raikar SR, Rao YV, Devika U. Development, implementation, and analysis of adverse drug reaction monitoring system in a rural tertiary care teaching hospital in Narketpally, Telangana. Int J Basic Clin Pharmacol. 2015;4(4):75760 .

19. Suthar JV, Desai SV. A study of adverse cutaneous drug reactions in outdoor patients attending to skin and V.D. Department of Shree Krishna Hospital, Karamsad. Int J Res Pharm Biomed Sci. 2011;2:22293701.

20. Jose J, Rao Padma GM, Jimmy B. Adverse drug reactions to fluoroquinolone antibiotics - analysis of reports received in a tertiary care hospital. Int J Risk Saf Med. 2008;20:169-80.
21. Jose J, Rao PG. Pattern of adverse drug reactions notified by spontaneous reporting in an Indian tertiary care teaching hospital. Pharmacol Res. 2006;54:22633.

22. Adithan S, Balamurugan N, Gunaseelan K, Akhtar S, Reddy KS, Adithan C. Adverse drug reaction profile of cisplatin-based chemotherapy regimen in a tertiary care hospital in India: An evaluative study. Ind $\mathbf{J}$ of Pharmac. 2010 Feb 1;42:40-3.

Cite this article as: Syed HF, Sathyanarayanan V, Jamuna Rani R. Analysis of adverse drug reactions encountered in a tertiary care hospital: a cross sectional study. Int J Basic Clin Pharmacol 2018;7:1164-8. 